\title{
Relaxin Regulates MMP Expression and Promotes Satellite Cell Mobilization During Muscle Healing in Both Young and Aged Mice
}

\author{
Xiaodong Mu, ${ }^{\dagger}{ }^{\dagger}$ Maria L. Urso, ${ }^{\ddagger}$ Kiley Murray, ${ }^{*}$ \\ Freddie $\mathrm{Fu},{ }^{\dagger}$ and Yong $\mathrm{Li}^{\star \dagger} \$$ \\ From the Laboratory of Molecular Pathology,* Stem Cell Research \\ Center, Children's Hospital of Pittsburgh of University of \\ Pittsburgh Medical Center, Pittsburgh, Pennsylvania; the \\ Departments of Orthopedic Surgery, ${ }^{\dagger}$ and Pathology, University \\ of Pittsburgh, Pittsburgh, Pennsylvania; and the Military \\ Performance Division, ${ }^{\ddagger}$ U.S. Army Institute of Environmental \\ Medicine (USARIEM), Natick, Massachusetts
}

The polypeptide hormone relaxin has been proven to be effective in promoting both the remodeling and regeneration of various tissues, including cardiac muscle. In addition, our previous study demonstrated that relaxin is beneficial to skeletal muscle healing by both promoting muscle regeneration and preventing fibrosis formation. However, the molecular and cellular mechanisms of relaxin in regulating both myogenic cell differentiation and muscle healing process are still unclear. In this study, C2C12 mouse myoblasts and primary human myoblasts were treated with relaxin to investigate its potential effect in vitro; relaxin was also injected intramuscularly into the injured site of the mouse on the second day after injury to observe its function in vivo, especially in the aged muscle. Results showed that relaxin promoted myogenic differentiation, migration, and activation of matrix metalloproteinases (MMPs) of cultured myoblasts in vitro. In the injured muscle, relaxin administration promoted the activation of Pax7-positive skeletal muscle satellite cells and increased its local population compared with nontreated control muscles. Meanwhile, both angiogenesis and revascularization were increased, while the extended inflammatory reaction was repressed in the relaxin-treated injured muscle. Moreover, relaxin similarly promoted muscle healing in mice with aged muscle. These results revealed the multiple effects of relaxin in systematically improving muscle healing as well as its potential for clinical applications in patients with skeletal muscle injuries and diseases. (Am J Pathol 2010, 177:2399-2410; DOI: 10.2353/ajpath.2010.091121)
The healing process of skeletal muscle usually includes sequential and overlapped phases of myofiber degradation, inflammatory reaction, regeneration, and fibrosis formation. ${ }^{1-4}$ The amount of activated muscle precursor cells is an important determinant for the efficiency of muscle regeneration and healing. The main source of muscle precursor cells are satellite cells (muscle stem cells), which normally reside beneath the basal lamina of myofibers and are activated to proliferate and migrate to the injured site by muscle injury and early inflammatory reaction. ${ }^{3-6}$ In the cases of aged muscle or some diseased muscle, it was discovered that satellite cells are either low in number or poorly activated for muscle regeneration, resulting in delayed healing with extensive formation of fibrotic scar tissue.$^{5,7-10}$ Recent studies have further indicated that during the healing of aged muscle, the systemic microenvironment is less effective in supporting and maintaining the activation, recruitment, and myogenic fate of resident muscle stem cells but facilitates a conversion to fibrogenic fate. ${ }^{11-12}$ Interestingly, evidence has shown that the hostile microenvironment of muscle regeneration is restorable by either neutralizing the activity of transformation growth factor (TGF)- $\beta 1^{12}$ or introducing activated matrix metalloproteinase (MMP)-9 during cell therapy. ${ }^{13}$

MMPs have positive roles in muscle healing by promoting muscle regeneration and reducing fibrosis, partially via their ability in inhibiting TGF- $\beta 1 .{ }^{14-18}$ Also, MMPs can degrade components of the extra cellular matrix (ECM) and facilitate inflammatory and myogenic cells migration through the ECM to the site of injury. ${ }^{18-20}$ Specifically, MMP1 (collagenase-1) directly digests the Type-I and III collagens of the ECM, and its administration promotes cell migration and myogenic differentiation in vitro as well as improves muscle healing in vivo. ${ }^{15,21-22}$ ECM degradation also results in the release or exposure

Supported by an NFL Charities, Medical grant made in 2008, and in part by National Institutes of Health and Department of Defense grants (Y.L.).

Accepted for publication July 14, 2010

Address reprint requests to Yong Li, M.D., Ph.D., Director, the Laboratory of Molecular Pathology Stem Cell Research Center (SCRC), Office 217, Bridgeside Point II, 450 Technology Drive Pittsburgh, PA 15219. E-mail: yongli@pitt.edu. 
of cytokines and growth factors to regulate cell proliferation and differentiation. ${ }^{20,23}$ Another critical event during muscle healing is inflammatory reaction, which initiates within the first few days after muscle injury and is necessary for cell debris removal, satellite cells activation, and triggering of muscle regeneration. 2,6,24 However, muscle healing is impeded with fibrosis formation and chronic pain if the inflammatory reaction is extended (chronic inflammation), which often occurs during the healing of aged muscle or severely injured muscle.,.$^{2,6,25-26}$ Therefore, inflammatory reaction and fibrotic scar formation are required to be balanced or controlled for muscle healing.

The polypeptide hormone relaxin is a member of the insulin-like growth factors (IGFs). ${ }^{27}$ Relaxin has a relaxant effect on blood vessels such as peripheral and coronary vasculature, ${ }^{28}$ promotes growth of blood vessels, ${ }^{29}$ and induces angiogenesis selectively at wound sites. ${ }^{30} \mathrm{It}$ is also able to regulate the immune system. ${ }^{31-32}$ More importantly, relaxin is suggested to be therapeutically useful for regulating excessive collagen deposition and promoting tissue remodeling in diseases characterized by fibrotic organs. ${ }^{27,33-37}$ The mechanism behind the antifibrotic effect of relaxin is still unclear, but it has been discovered to prevent the influence of some profibrotic factors (ie, TGF$\beta 1$, angiotensin $\mathrm{I} / \mathrm{Ang} \mathrm{I}$, and interleukin- $1 \beta)^{35,38-40}$ and stimulate the activation of MMPs in some tissues. ${ }^{38}$

Recent in vitro studies suggested that relaxin administration improves myogenic differentiation of primary murine cardiomyocyte cell cultures. ${ }^{41}$ Evidence from in vivo studies suggested that relaxin can favor cardiac muscle tissue remodeling and myocardial performance by inducing neoangiogenesis and ECM turnover in postinfarction heart repair. ${ }^{42-43}$ Our previous work has also discovered that relaxin treatment improved skeletal muscle healing based on its antifibrotic effect in traumatically injured mouse models. ${ }^{33,44}$ In this study, we further examined the molecular and cellular mechanisms of relaxin in improving skeletal muscle healing, and investigated whether relaxin can regulate MMPs expression of myogenic cells and whether relaxin can regulate the activation of muscle precursors, angiogenesis, and inflammatory reaction in injured muscle. In addition, we studied whether relaxin can be effective in promoting the healing of aged skeletal muscle, as another member of the IGF-IGF-1-was suggested to potentially achieve. ${ }^{45}$ Because the Phase II/III clinical trials of relaxin are being studied and have shown promising results, such as the treatment of acute heart failure, ${ }^{46}$ we are hoping that our study could shed light on the possible application of relaxin in therapeutic treatment of skeletal muscle with injuries or diseases.

\section{Materials and Methods}

\section{Myogenic Differentiation Assay}

C2C12 myoblasts (purchased from ATCC, Manassas, VA) or primary human myoblasts (obtained from our stem cell center) were treated with or without relaxin (1000 $\mathrm{ng} / \mathrm{ml}$ of porcine relaxin from Sky BioHealth Solutions Inc, St. Paul, MN; this relaxin had been verified for its effect on
cAMP production in THP1 cells ${ }^{47}$ ) and cultured in differentiation medium [DMEM (Invitrogen, Carlsbad, CA) supplemented with $2 \%$ Horse Serum (HS), 1\% PenicillinStreptomycin antibiotics (P/S)], and incubated in $5 \% \mathrm{CO}_{2}$ at $37^{\circ} \mathrm{C}$. MMP blocker GM6001 (Millipore, Billerica, MA) was applied at $10 \mu \mathrm{mol} / \mathrm{L}$. IC50 of GM6001 is in low$\mathrm{nmol} / \mathrm{L}$ range at the molecular level, but for the cultured cells it is usually increased to $5-25 \mu \mathrm{mol} / \mathrm{L}$ to be effective. ${ }^{48}$ The treated cells were cultured in differentiation medium (DMEM supplemented with $2 \%$ HS) up to 4 days for myotube formation. The myotubes were identified by the expression of fast-type myosin heavy chain $(\mathrm{MHC})$ or MyoD to show the advancing stages of differentiation.

\section{Relaxin Treatment of Myogenic Cells for Quantitative RT-PCR Study}

C2C12 primary human myoblasts were cultured with different concentration of relaxin $(0,200,1000 \mathrm{ng} / \mathrm{ml})$ for 30 hours (hrs) in proliferation medium [DMEM supplemented with $10 \% \mathrm{FBS}, 10 \% \mathrm{HS}$, and $1 \% \mathrm{P} / \mathrm{S}$. Total RNA was then obtained from cells by using the RNeasy Mini Kit (Qiagen, Valencia, CA). Reverse transcription (RT) was performed using the iScript cDNA Synthesis Kit (Bio-Rad, Hercules, CA). The primers for RT-PCR are shown in Table 1. Human primers MMP1, MMP2, and TIMP1 were obtained from a commercial source (Real Time Primers, Elkins Park, PA). The following primers were selected from Primer Bank: mouse MMP1 (14030785a1), mouse MMP2 (6678902a1), mouse MMP3 (6754714a1), human MMP3 (4505217a2), mouse MMP9 (7305277a1), human MMP9 (4826836a2), mouse TIMP1 (6755795a2), human TIMP2 (4507511a2), human TIMP3 (4507513a2), mouse TIMP4 (31981528a1), human TIMP4 (4507515a3), mouse Pax7 (34328055a1), and human Pax7 (4505619a1). The cycling parameters used for all primers were as follows: $95^{\circ} \mathrm{C}$ for 10 minutes; PCR 40 cycles of: 30 seconds $95^{\circ} \mathrm{C}$ denaturation, 1 minute $53^{\circ} \mathrm{C}-62^{\circ} \mathrm{C}$ annealing, 30 seconds $72^{\circ} \mathrm{C}$ extension were repeated. A DNA dissociation curve was performed for each sample to ensure the purity of amplification products. Results of all of the genes were normalized in relation to $\beta$-actin expression. Correlation coefficient ( $\geq 0.98$ ) and amplification efficiencies (90 to 110\%) were calculated by using the Bio-Rad iQ5 software.

\section{In Vitro Wound Healing Study}

C2C12 myoblasts were seeded in collagen-coated 12-well plates and grown in proliferation medium. C2C12 cells with or without relaxin (1000 $\mathrm{ng} / \mathrm{ml}$ ) or GM6001 (10 $\mu \mathrm{mol} / \mathrm{L})$ treatment were cultured for approximately 24 hours until cells reached $80 \%$ confluence. Artificial wounds were then created as described previously ${ }^{15}$ to the cells in the proliferation medium, and migration distances (Microns) of $\mathrm{C} 2 \mathrm{C} 12$ cells into the wounded area were measured 7 hours after the creation of the wound. The deposition of Pax7 and p21 proteins was also determined. 
Table 1. Primers for Real-Time PCR

\begin{tabular}{|c|c|c|c|}
\hline \multirow[b]{2}{*}{ Gene } & \multicolumn{2}{|c|}{ Primer sequences } & \multirow[b]{2}{*}{ Size $(b p)$} \\
\hline & Sense & Antisense & \\
\hline \multirow[t]{2}{*}{$M M P-1$} & Human: 5'-CATGACTTTCCTGGAATTGG-3' & 5'-CCTGCAGTTGAACCAGCTAT-3' & 150 \\
\hline & Mouse: 5'-AACTACATTTAGGGGAGAGGTGT-3' & 5'-GCAGCGTCAAGTTTAACTGGAA-3' & 132 \\
\hline \multirow[t]{2}{*}{ MMP-2 } & Human: 5'-TTGACGGTAAGGACGGACTC-3' & $5^{\prime}-$ ACTTGCAGTACTCCCCATCG-3' & 152 \\
\hline & Mouse: 5'-CAAGTTCCCCGGCGATGTC-3' & $5^{\prime}$-TTCTGGTCAAGGTCACCTGTC-3' & 171 \\
\hline \multirow[t]{2}{*}{ MMP-3 } & Human: 5'-ATGGACAAAGGATACAACAGGGA-3' & 5'-TGTGAGTGAGTGATAGAGTGGG-3' & 127 \\
\hline & Mouse: 5'-ACATGGAGACTTTGTCCCTTTTG-3' & $5^{\prime}-$ TTGGCTGAGTGGTAGAGTCCC-3' & 192 \\
\hline \multirow[t]{2}{*}{ MMP-9 } & Human: 5'-GGGACGCAGACATCGTCATC-3' & 5'-TCGTCATCGTCGAAATGGGC-3' & 139 \\
\hline & Mouse: 5'-CTGGACAGCCAGACACTAAAG-3' & $5^{\prime}$-CTCGCGGCAAGTCTTCAGAG-3' & 145 \\
\hline \multirow[t]{2}{*}{ TIMP-1 } & Human: 5'-TACTTCCACAGGTCCCACAA-3' & 5'-ATTCCTCACAGCCAACAGTG-3' & 165 \\
\hline & Mouse: 5'-CTTGGTTCCCTGGCGTACTC-3' & $5^{\prime}-\mathrm{ACCTGATCCGTCCACAAACAG-3^{ \prime }}$ & 153 \\
\hline TIMP-2 & Human: 5'-AACGACATTTATGGCAACCCT-3' & 5'-CTTCTCAGGCCCTTTGAACAT-3' & 78 \\
\hline TIMP-3 & Human: 5'-CATGTGCAGTACATCCACACG-3' & $5^{\prime}$-ACATCTTGCCATCATAGACGC-3' & 109 \\
\hline \multirow[t]{2}{*}{ TIMP-4 } & Human: 5'-CTGCTACACAGTACCCTGTACC-3' & $5^{\prime}-$ TGCCGTCAACATGCTTCATAC-3' & 125 \\
\hline & Mouse: 5'-TGTGGCTGCCAAATCACCA-3' & $5^{\prime}-$ TCATGCAGACATAGTGCTGGG-3' & 130 \\
\hline \multirow[t]{2}{*}{ Pax7 } & Human: 5'-ACCCCTGCCTAACCACATC-3' & $5^{\prime}$-GCGGCAAAGAATCTTGGAGAC-3' & 121 \\
\hline & Mouse: 5'-TCTCCAAGATTCTGTGCCGAT-3' & 5'-CGGGGTTCTCTCTCTTATACTCC-3' & 132 \\
\hline LGR-7 & Human: 5'-TGCCCATTAACAGTGCTTTG-3' & $5^{\prime}$-GGTCCGGCTTCATTAACTCA-3' & 180 \\
\hline \multirow[t]{2}{*}{$\beta$-actin } & Human: 5'-AGCGGGAAATCGTGCGTG-3' & $5^{\prime}$-CAGGGTACATGGTGGTGCC-3' & 300 \\
\hline & Mouse: 5'-GGGTCAGAAGGACTCCTATGTGG-3' & $5^{\prime}$-CCTGGATGGCTACGTACAT-3' & 272 \\
\hline
\end{tabular}

\section{Relaxin Administration in Injured Skeletal Muscle}

The use of animals and the surgical procedures performed in this study were approved by the Institutional Animal Care and Use Committee (IACUC) of University of Pittsburgh Medical Center. Gastrocnemius (GM) muscles in both hind legs of mice (C57BL/6J, male, 5 weeks or 18 months of age, Jackson lab, Bar Harbor, ME) were laceration-injured as described previously. ${ }^{21,33}$ After the completion of pilot experiments to determine the optimum concentration, a microsyringe (Hamilton, Reno, NV) was used to inject 10 $\mu \mathrm{g} / \mathrm{ml}$ of relaxin in $40 \mu \mathrm{l}$ of phosphate-buffered saline solution (PBS) at the site of injury (left legs), or $40 \mu$ of PBS alone as control (right legs). This injection was conducted 1 day after laceration and repeated every 3 days. All animals were sacrificed 5 days (young and aged mice) or 10 days (aged mice) after injury, and all GM muscles were harvested to obtain cryo-sections for histological and immunohistochemical analysis. At least four mice were used for each condition (young/5 days, aged/5 days, and aged/10 days).

\section{Zymography}

C2C12 myoblasts were treated with relaxin $(0,200,1000$ $\mathrm{ng} / \mathrm{ml}$ ) for 48 hours. Cells were then homogenized in RIPA buffer (Sigma \#R0278 St. Louis, MO) without the presence of EDTA and prepared for nonreduced SDS-PAGE via exclusion of 2-Mercaptoethanol in the protein lysate used for zymography. Culture medium of the cells was also harvested for zymography study. Skeletal muscle tissues (relaxin-treated and nontreated GM) were also collected and homogenized in RIPA buffer to conduct zymography study. Nonreduced denatured protein $(15 \mu \mathrm{g})$ was heated for five minutes at $95^{\circ} \mathrm{C}$ to dissolve SDS and resolved on $10 \%$ Criterion Zymogram gelatinase gels (Bio-Rad \#161-1185). After SDS-PAGE, denatured and resolved proteins were renatured by incubating the gels at room temperature (RT) overnight with gentle agitation in renaturation buffer consisting of $2.5 \%$ Triton-X 100 and $5 \mathrm{mmol} / \mathrm{L} \mathrm{CaCl}_{2}$. For development, gelatin degradation was performed via 24 hours in- cubation at $37^{\circ} \mathrm{C}$ with gentle agitation in development buffer (50 mmol/L Tris, pH 7.5, $200 \mathrm{mmol} / \mathrm{L} \mathrm{NaCl}, 10 \mathrm{mmol} / \mathrm{L}$ $\mathrm{CaCl}_{2}$ ). Gels were stained with a $50 \% \mathrm{MeOH} / 10 \%$ acetic acid solution with 0.5\% Coomassie Blue R-250 (Bio-Rad \#161-0400) at RT for 2 hours with gentle agitation followed by gel destaining with $50 \% \mathrm{MeOH} / 10 \%$ acetic acid solution at RT until desired contrast was achieved. Bands were visualized for qualitative comparison. Clear bands of lysis represent levels of gelatinase activity and represent MMP2 and MMP9 zymogen activity at corresponding molecular weights. Methods are modifications of Lluri and Jaworski, ${ }^{49}$ Das et al, ${ }^{50}$ and Bio-Rad's Criterion Precast Gel Application Guide (\#345-0000).

\section{Immunofluorescent Staining of Cells and Tissue Sections}

Cultured cells were fixed with $4 \%$ paraformaldehyde (10 minutes), and skeletal muscle cryo-sections were fixed with $4 \%$ formalin (10 minutes). Cross sections, but not longitudinal sections of muscle tissues, were analyzed, since cross sections are suitable for observing histological myofibers, which are usually not linearly straight. Longitudinal sections would not allow us to track a single longitudinal fiber. Also, cross sections are widely used in muscle tissue studies. In our studies, with cross sections, we are able to identify centrally nucleated myofibers to localize new-forming or regenerating myofibers. ${ }^{48}$ After washing the samples with PBS, $10 \%$ HS was used to block nonspecific binding for 1 hour. The primary antibodies: MHC (Sigma \#m4276; 1:200), p21 (Santa Cruz \#554085; Santa Cruz, CA; 1:200), CD8a (BD Biosciences \#550281, San Jose, California; 1:200), CD11b (BD Biosciences \#557394; 1:200), Pax7 (DHSB \#Pax7-c, lowa City, IA; 1:100), CD31 (BD Biosciences \#553370; 1:200), dystrophin (Abcam \#15277; Cambridge, MA; 1:200), utrophin (Santa Cruz \#7459; 1:200), and TGF- $\beta 1$ (Novocastra Laboratories, NCL-TGF- $\beta$; UK; 1:300) were applied. For antibodies produced in mice (ie, Pax7), the Vec- 

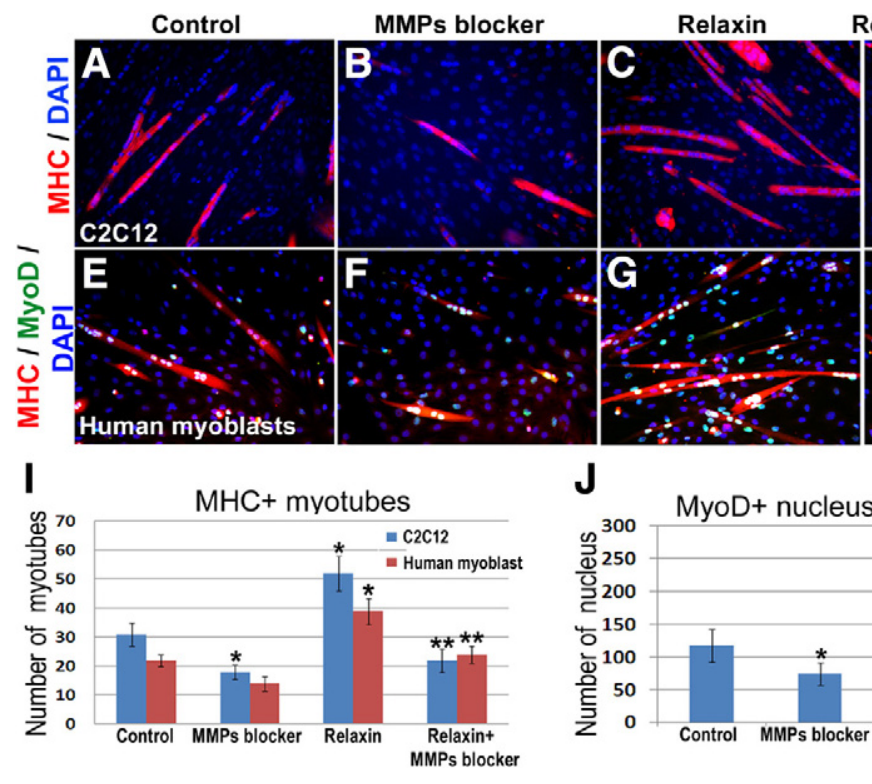

Relaxin + MMPs blocker

tor Mouse on Mouse (MOM) Kits (Vector Labs, Burlingame, CA) were used for improving antibody specificity. Secondary antibodies were Alexa Fluor 488 or 594 specific to various species (Invitrogen; 1:400). DAPI counterstaining was conducted to localize cell nuclei. Fluorescence microscopy (Leica Microsystemic Inc., Bannockburn, IL) was used to examine all of the immunofluorescence results and capture photographic images.

\section{Measurement of Results and Statistical Analysis}

The measurement of myogenic differentiation capacity, cell migration, cells positive for various proteins or cell markers (MHC, p21, Pax7, CD8a, CD11b, dystrophin, or utrophin), and percentage of area positive for CD31 signal or new myofibers in the injured areas was conducted with Northern Eclipse software (version 6.0, Empix Imaging Inc., Mississauga, ON, Canada) and ImageJ software (version 1.32j, National Institutes of Health, Bethesda, MD). At least three identically treated cell cultures, or tissue sections from four identically treated mice for each group were used to generate the data; data were analyzed based on three pictures of each cell culture or tissue section. Therefore, at least three samples obtained from each subject were pooled for statistical analysis. All of the results from this study are expressed as the mean $\pm S D$. The differences between means were considered statistically significant if $P<0.05$. The analysis of variance test was used to compare the differences between different groups of cells or tissue sections.

\section{Results}

\section{Relaxin Promotes Myogenic Cell Differentiation in Vitro, and this Effect can be Compromised by MMP Blocker}

Our previous study has verified the concentration-dependent effect of relaxin in promoting myogenic differ-

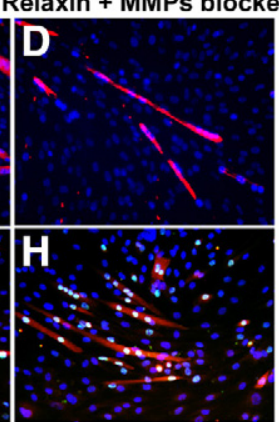

Figure 1. MMP blocker GM6001 compromises the relaxin promoted myogenic differentiation. A-D: Immunostaining of myosin heavy chain (MHC, red) in C2C12 cells without treatment (A), with treatment of GM6001 (10 $\mu \mathrm{mol} / \mathrm{L} ; \mathbf{B})$, with treatment of relaxin $(1000 \mathrm{ng} / \mathrm{ml} ; \mathbf{C})$, and with ***treatment of relaxin $(1000 \mathrm{ng} / \mathrm{ml})$ plus MMP blocker $(10 \mu \mathrm{mol} / \mathrm{L} ; \mathbf{D})$. E-H: Immunostaining of MHC (red) and MyoD (green) in human myoblasts without treatment $(\mathbf{E})$, with treatment of GM6001 $(10 \mu \mathrm{mol} / \mathrm{L} ; \mathbf{F})$, with treatment of relaxin $(1000 \mathrm{ng} / \mathrm{ml} ; \mathbf{G})$, and with treatment of relaxin $(1000 \mathrm{ng} / \mathrm{ml})$ plus MMP blocker (10 $\mu \mathrm{mol} / \mathrm{L} ; \mathbf{H}) . \mathbf{I}$ and $\mathbf{J}$ : Statistical analysis of the number of MHC+ myotubes $(\mathrm{C} 2 \mathrm{C} 12$ and human myoblasts) (I) or MyoD+ nucleus (human myoblasts; J) in an area of $1 \mathrm{~cm}^{2}$ in the dish. Error bars represent SE of the mean of triplicate samples. There is a significant difference $\left({ }^{*} P<0.05\right)$ from the group without treatment (control). There is a significant difference from the group with relaxin treatment (relaxin, ${ }^{* *} P<0.05$ ). entiation of C2C12 myoblasts. ${ }^{33}$ Here we further studied the possible effect of relaxin on human myoblasts and its possible correlation with MMP activities. C2C12 or primary human myoblasts were cultured in differentiation medium for 4 days. There were four groups of cells: no treatment, treatment with MMP blocker GM6001, treatment with relaxin $(1000 \mathrm{ng} / \mathrm{ml})$, and treatment with both relaxin and GM6001. GM6001 was applied here as a potent inhibitor of MMP activity, including MMP1, MMP2, MMP3, MMP8, and MMP9. ${ }^{51}$ After 4 days of culture, cultured cells containing multinucleated myotubes were immunostained with antibody against $\mathrm{MHC}$. Results showed that compared to the control cells (Figure 1, A and E), more myotubes were formed in the relaxin treated cells (Figure 1, C, G, $\mathrm{I}$, and $\mathrm{J}$ ), as verified by more myotubes positive with myosin heavy chain (MHC) or MyoD, indicating that relaxin treatment promoted myogenic differentiation of myoblasts. It also shows that GM6001 treatment alone reduced the number of myotubes (Figure 1, B and F), and the myogenic differentiation promoted by relaxin treatment was greatly repressed when GM6001 was applied simultaneously (Figure 1, D and H). This observation indicates that relaxin cannot overcome the inhibitory effect of MMP blocker on myogenic differentiation. However, with this result, it is still not certain whether relaxin can regulate MMP expression and activation in the myoblasts, which require further investigation.

\section{Relaxin Up-Regulates MMP Expression and Promotes MMP Activation in Cultured Myogenic Cells}

To verify the effect of relaxin on MMP expression, a quantitative RT-PCR study was conducted with C2C12 and human myoblasts cultured with different concentration of relaxin $(0,200$, or $1000 \mathrm{ng} / \mathrm{ml})$ for 30 hours. We tested the mRNA level of some MMPs having reg- 
A

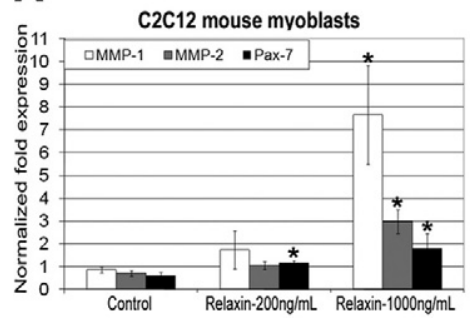

C

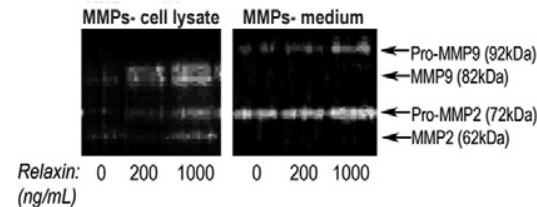

B

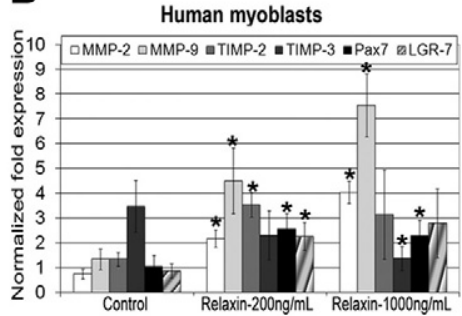

D

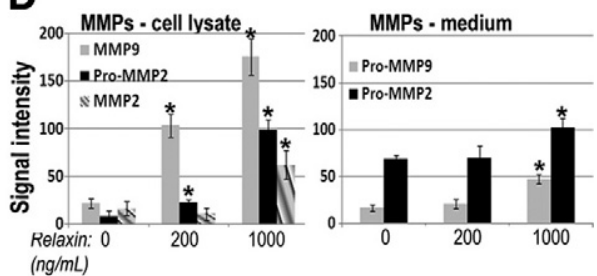

Figure 2. Quantitative RT-PCR and zymography studies of relaxin-treated $\mathrm{C} 2 \mathrm{C} 12$ myoblasts. A and $\mathbf{B}$ : With different concentrations of relaxin treatment $(0,200$, or $1000 \mathrm{ng} / \mathrm{ml})$, mRNA level of MMP1, MMP2, and Pax7 in C2C12 cells (A), and MMP2, MMP9, TIMP2, TIMP3, Pax7, and LGR-7 in human myoblasts are shown (B). C: With different concentrations of relaxin treatment $(0$, 200 , of $1000 \mathrm{ng} / \mathrm{ml}$ ), the level of active or proactive types of MMP2 and MMP9 within cells or culture medium were analyzed with zymographic assay (gelatinase gel). D: Readout of the signal intensities in the gel, which is in correspondence with MMP activities. There is a significant difference $\left({ }^{*} P<0.05\right)$ from the group without treatment (control) ulatory roles in skeletal muscle development or healing, including MMP1, 2, 3, 9, and the tissue inhibitors of MMPs (TIMP) 1, 2, 3, and 4. Results showed that relaxin treatment can significantly up-regulate the expression of MMP1 and MMP2 in C2C12 cells (Figure 2A), and MMP2, MMP9, and TIMP2 in human myoblasts (Figure 2B). However, TIMP-3 expression was down-regulated in human cells treated with relaxin (Figure 2B). The expression of other types of MMPs or TIMPs in this study was found to be unaffected by relaxin. Although TIMP2 is generally an inhibitor of MMP activity, TIMP2 can also perform MMP-independent functions during myogenesis, ${ }^{49}$ and it still plays a role in activating MMP2 ${ }^{52}$ and cooperating with MMP2 in regulating muscle cell differentiation. ${ }^{49}$ Therefore, these results show that the expression of MMPs in myogenic cells was generally up-regulated by relaxin stimulation.

To further verify the effect of relaxin on MMP activities, zymographic assay of MMPs were performed with C2C12 myoblasts cultured with different concentrations of relaxin $(0,200$, or $1000 \mathrm{ng} / \mathrm{ml})$ for 48 hours. With gelatinase gel, the gelatinase activities (MMP2 and MMP9) in both extracted proteins (MMPs in cell lysate) and culture medium (MMPs in medium) of the relaxin-treated cells were studied. Results showed that, in the cell lysate, active MMP2, active MMP9, and pro-MMP9 were increased after relaxin treatment (Figure 2, B-D); in the culture medium, both pro-MMP2 and pro-MMP9 were increased after relaxin treatment (Figure 2, B-D).

Therefore, MMP expression and activation in myogenic cells were found to be generally promoted by relaxin stimulation. Our qRT-PCR results also showed that the expression of Pax7 (skeletal muscle satellite cell marker $)^{53-54}$ was promoted by relaxin treatment in both cell types (Figure 2A), which may be consistent with the effect of relaxin in promoting myogenic differentiation. In addition, the expression of the relaxin receptor LGR-7 in human myoblasts was up-regulated (Figure 2B), which indicates that the effect of relaxin on human myoblasts may be related with the LGR-7 pathway. ${ }^{55}$

\section{Relaxin Promotes Myogenic Cell Migration and Modifies the Population of Pax7 or p21 Positive Cells in Vitro, and These Effects Can Be Compromised by MMP Blocker}

Because MMP activation was observed in the relaxintreated myogenic cells and MMPs are involved with regulation of cell migration and proliferation, ${ }^{15,18-20}$ an improved cell migration or proliferation may be expected with relaxin treatment of the cells. We investigated this hypothesis with an in vitro wound healing study. Results showed that, compared to the control cells (Figure 3, A and E), MMP blocker did not inhibit the cell migration (Figure 3, B and E), which may be due to very low basal MMP activity in the control cells; relaxin treatment of the cells promoted cell migration (Figure 3, C and E), while MMP blocker greatly compromised this effect (Figure 3, D and E). Meanwhile, immunostaining of the $\mathrm{p} 21$ and $\mathrm{Pax} 7$ proteins showed that fewer p21-positive cells but more Pax7-positive cells were detected in the relaxin-treated cells (Figure 3, C and F) compared to the control cells (Figure 3, A and $F$ ), which effects were also more or less changed by MMP blocker (Figure 3, D and F). p21, an inhibitor of cyclin-dependent kinases (CDKs), is a negative regulator of cell cycle, and its repression is critical for cell proliferation. ${ }^{56-57} \mathrm{Pax} 7$ is a cell marker of satellite cells that are highly myogenic and self-renewable, and Pax7 directly regulates proliferation and differentiation of myogenic cells. ${ }^{53-54}$ Therefore, our results indicated that the migration, proliferation, and myogenic differentiation potentials of the myogenic cells may be promoted with relaxin treatment, possibly by regulating MMP activity. 


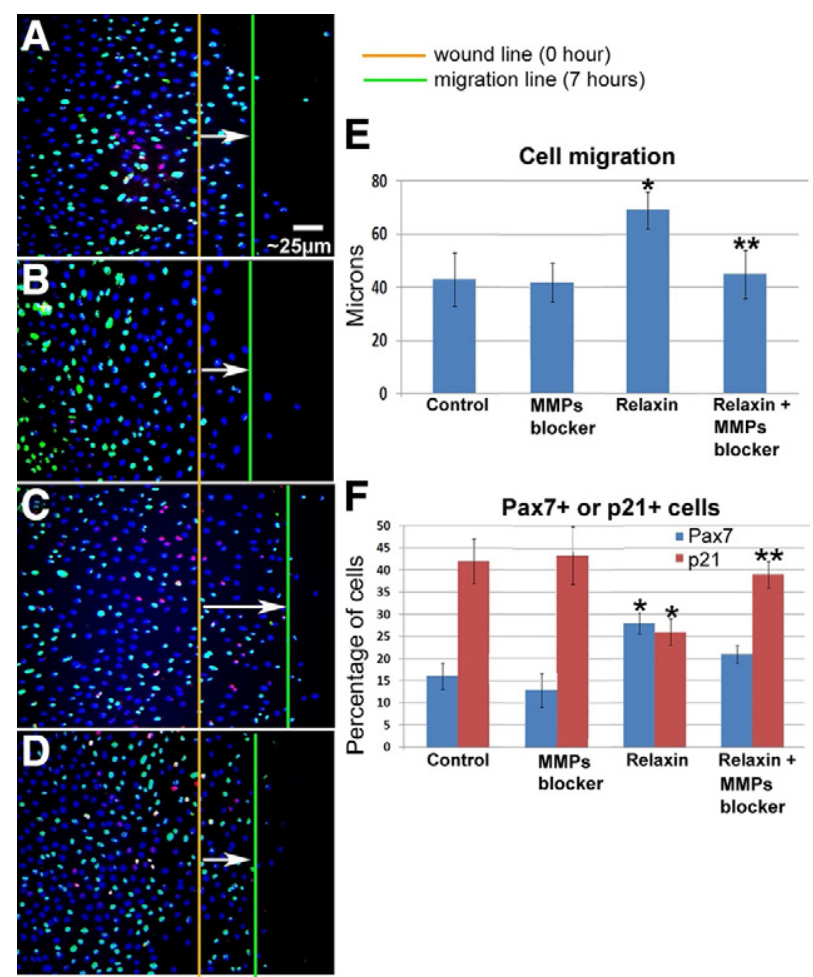

Figure 3. Effect of relaxin and MMP blocker on C2C12 cell migration and the population of Pax7- or p21-positive cells. A-D: In an in vitro wound model, MMP blocker (B) did not inhibit the cell migration; relaxin treatment (1000 $\mathrm{ng} / \mathrm{ml}$; C) promoted cell migration compared to the nontreated control (A), while MMP blocker compromised relaxin-promoted cell migration (D). The orange line indicates the initial edge of the wound, and the green line indicates the position of cells after 7 hours of migration into the wound area. Arrow indicates the direction of cell migration. The deposition of Pax7 (red) and p21 (green) proteins were also affected with application of relaxin or MMP blocker (A-D). Nuclei are counterstained as blue. E: Statistical analysis of migration distances (microns) of the three groups of cells. F: Statistical analysis of percentage of Pax7+ or p21+ cells. There is a significant difference $\left({ }^{*} P<0.05\right)$ from the group without treatment (control). There is significant difference from the group with relaxin treatment (relaxin, ${ }^{* *} P<0.05$ ).

\section{Relaxin Increases the Population of Pax7-Positive Satellite Cells, Improves Angiogenesis, and Represses Inflammatory Reaction in the Injured Muscle}

In our previous study, relaxin was injected into skeletal muscle 3 days, 1 week, or 2 weeks after muscle injury, resulting in promoted muscle regeneration and reduced fibrosis that were observed 3 to 4 weeks later. ${ }^{33}$ However, the effects and mechanism of relaxin at early phases (within one week) of muscle healing are still unclear. It would be very interesting to find out whether relaxin can directly regulate the activation of muscle progenitor cells, angiogenesis/re-vascularization, and inflammatory reaction, which are all critical events at early phases of muscle healing.

Satellite cells are a group of undifferentiated skeletal muscle progenitor cells which are usually quiescent in normal muscle. The mobilization of satellite cells for muscle healing is initiated when the inflammatory reaction releases various growth factors/cytokines at the injured site. $^{2,6}$ The efficient activation and proliferation of satellite

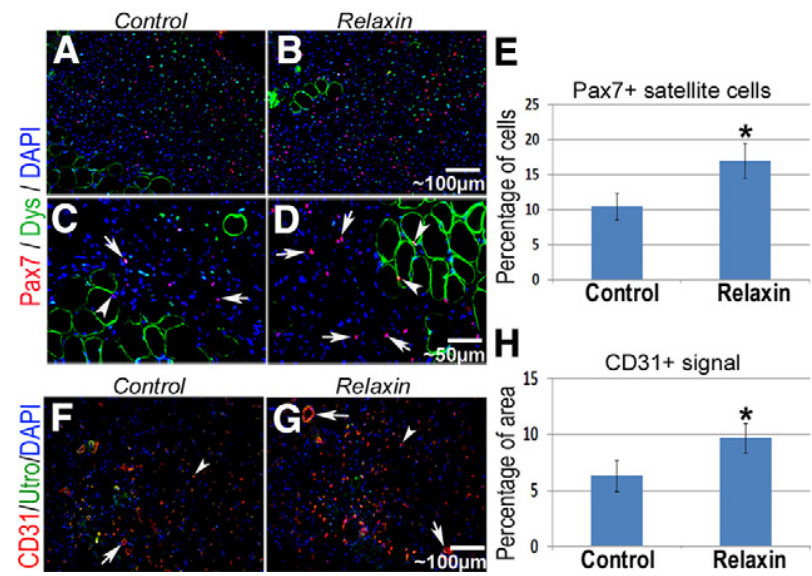

Figure 4. Relaxin administration improved satellite cell population and angiogenesis in injured muscle of 5-week-old mice. A-D: Five days after muscle injury and 4 days after relaxin injection, there were more Pax7+ satellite cells (red) present in the relaxin treated muscles (B and $\mathbf{D}$ ) compared to the control muscles ( $\mathbf{A}$ and $\mathbf{C}$ ). The nondamaged myofibers around the injured area were shown with positive dystrophin (Dys, green). Image $\mathbf{C}$ or $\mathbf{D}$ is $\times 2$ magnification of image $\mathbf{A}$ or $\mathbf{B}$. Some satellite cells were quiescent and localized beneath the basal lamina of myofibers (arrowheads); others were activated and had migrated into the injured area (arrows). E: Statistical analysis of the percentage of Pax $7+$ cells among all of the mononuclear cells at the area of muscle injury. $\mathbf{F}$ and $\mathbf{G}$ : There was more CD31 signal (red) in single endothelial cells (angiogenesis, arrowhead) or blood vessels (revascularization, arrows) in the injured muscles with relaxin administration (G), compared to the control muscles (F). Utrophin (Utro, dystrophin-related protein, green) was immunostained to localize myofibers and relatively mature blood vessels, both of which did not seem to be obvious in either group of injured muscle at the time ( 5 days after injury). H: Statistical analysis of the percentage of $\mathrm{CD} 31+$ signal at the area of muscle injury. There is a significant difference $\left({ }^{*} P<0.05\right)$ from the group without treatment (control).

cells are critical steps for muscle healing. ${ }^{4-5}$ In this study, GM muscles of mice were laceration-injured and then injected with relaxin on the second day. Relaxin injections were repeated every 3 days. Five days after injury, when satellite cells were activated and proliferating, muscles were harvested for tissue cryo-sectioning. Immunohistochemical studies revealed more Pax7-positive cells in the relaxin-treated muscles, compared to the nontreated control muscles (Figure 4, A-E). Whereas, the signal of endothelial cell marker CD31 was also found to be increased in the relaxin-treated muscles (Figure $4, \mathrm{~F}-\mathrm{H}$ ), indicating that angiogenesis/revascularization was promoted.

To find out the potential effect of relaxin on inflammatory reaction in the injured muscle, the numbers of inflammatory cells (CD8a- or CD11b-positive cells) at injured sites with and without relaxin administration were compared at 5 days postinjury. CD8a is an inflammatory cell marker related to macrophages and T lymphocytes, and CD11b is an inflammatory cell marker related to neutrophils and macrophages. ${ }^{58-60}$ Results showed that the number of CD8a-positive cells was significantly decreased (Figure 5, A-E) and the number of CD11b-positive cells was slightly (but not significantly) decreased (Figure 5, F-H) in the relaxin-treated muscles compared to the nontreated control muscles. These results indicate that the number of inflammatory cells was generally decreased with relaxin treatment in the injured muscle, which may therefore reduce the risk of extended inflammation and fibrosis formation. 


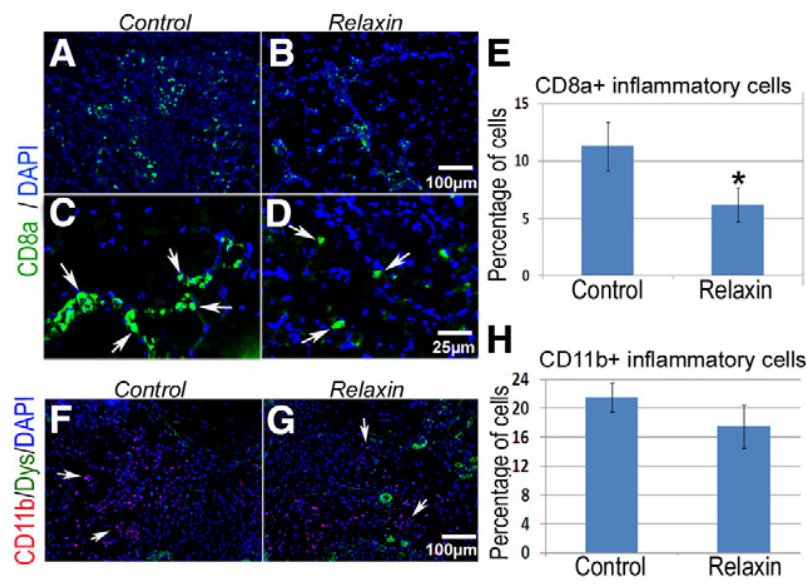

Figure 5. Relaxin administration affected inflammatory reaction in injured muscle of 5-week-old mice. A-D: Five days after muscle injury and 4 days after relaxin injection, the number of CD8a+ inflammatory cells (green, arrows) in the relaxin-treated muscles ( $\mathbf{B}$ and $\mathbf{D})$ was reduced compared to the control muscles (A and $\mathbf{C}$ ). Image $\mathbf{C}$ or $\mathbf{D}$ is $\times 4$ magnification of image $\mathbf{A}$ or $\mathbf{B}$. E: Statistical analysis of the percentage of CD8a + cells among all of the mononuclear cells at the area of muscle injury. $\mathbf{F}$ and $\mathbf{G}$ : The number of $\mathrm{CD} 11 \mathrm{~b}+$ cells (red, arrows) showed no obvious difference between relaxintreated muscles $(\mathbf{G})$ and the control muscles $(\mathbf{F})$. Myofibers were visualized with dystrophin (Dys, green). H: Statistical analysis of the percentage of $\mathrm{CD} 11 \mathrm{~b}+$ cells among all mononuclear cells at the area of muscle injury. There is a significant difference $\left({ }^{*} P<0.05\right)$ from the group without treatment (control).

\section{Relaxin Administration Improves Muscle Healing of Aged Muscle}

Aged muscle harbors very few satellite cells compared to young muscle, ${ }^{8}$ and a comparison between our young (5 weeks) and aged (18 months) mouse models is shown (Figure 6, A-C). The limited amount of satellite cells, and their poor ability to proliferate and differentiate in response to muscle injury, could be important reasons leading to slower muscle healing with increased fibrosis formation. ${ }^{7-8}$ Also, an improved local microenvironment favorable to satellite cell functioning is especially necessary for the healing of aged muscle..$^{9,11}$ Here we hypothesized that relaxin-promoted satellite cell activation and muscle regeneration in younger muscle may be repeatable in the aged muscle. To verify this possibility, GM muscles of 18-month-old mice were laceration-injured and then injected with relaxin on the second day. Relaxin injections were repeated every 3 days and the muscles were harvested 5 or 10 days after injury. Five days after muscle injury, the populations of Pax7-positive cells in the relaxin-treated muscles and the control muscles showed no significant difference (Figure 6, D-F); the inflammatory reaction reflected by the number of cells positive with inflammatory cell marker (CD8a but not CD11b) seemed to be inhibited by relaxin treatment (Figure 6, G-L). However, a significant difference was found in the number of Pax7-positive satellite cells between the two groups of muscles 10 days after injury (Figure 7, A-F). Results also show that new myofibers had been formed faster in the relaxin-treated muscle compared to the nontreated control muscle (Figure 7F). Cell nuclei in the nondamaged myofibers are always adjacent to the cell membrane, which is positive with dystrophin signal (Figure 7, A and

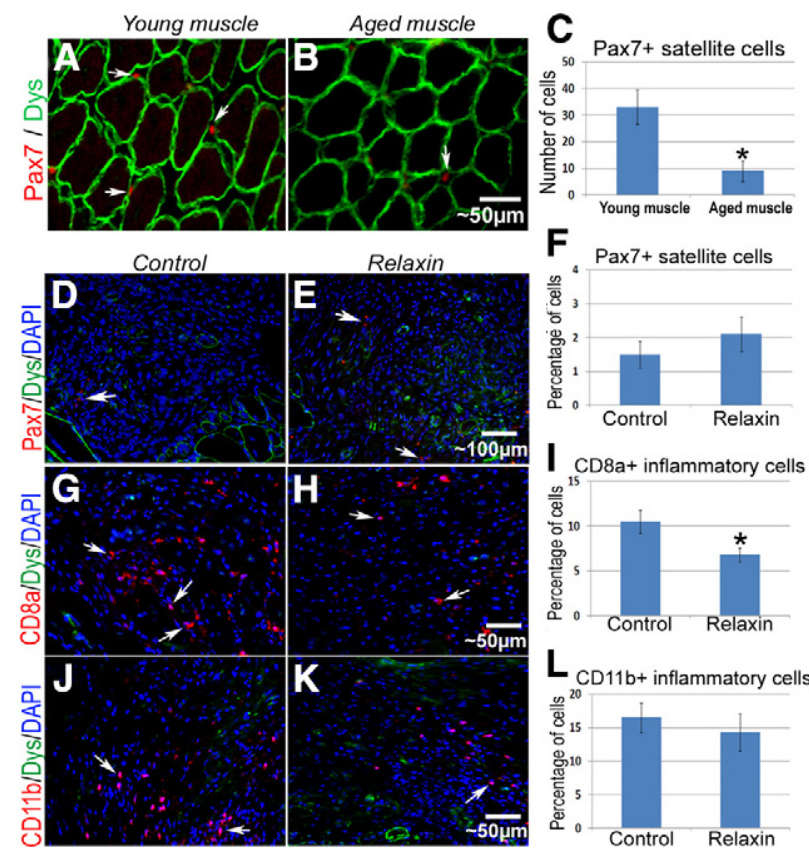

Figure 6. Effect of relaxin administration in injured muscle of 18-month-old mice 5 days after injury. $\mathbf{A}$ and $\mathbf{B}$ : The number of Pax $7+$ satellite cells (red, arrows) were found to be greatly reduced in the aged muscle of 18-monthold mice (B) compared to the young muscle of 5-week-old mice (A). C Statistical analysis of the number of Pax7 + cells among every 100 dystrophin + myofibers (green). D and E: Five days after muscle injury and 4 days after relaxin injection, the relaxin-treated muscles (E) showed a slight (but not significant) increase in the number of Pax7+ satellite cells (red, arrows) compared to the control muscles (D). Myofibers are visualized with dystrophin (Dys, green). F: Statistical analysis of the percentage of Pax7+ cells among all of the mononuclear cells at the area of muscle injury. $\mathbf{G}$ and $\mathbf{H}$ : The number of CD8a + inflammatory cells (red, arrows) was reduced in the relaxin-treated muscles (H) compared to the control muscles (G). I: Statistical analysis of the percentage of CD8a + cells among all of the mononuclear cells at the area of muscle injury. $\mathbf{J}$ and $\mathbf{K}$ : The number of CD11b+ inflammatory cells (red, arrows) was slightly reduced (but not significantly) in the relaxintreated muscles (K) compared to the control muscles (J). L: Statistical analysis of the percentage of CD11b+ cells among all of the mononuclear cells at the area of muscle injury. There is a significant difference $\left({ }^{*} P<0.05\right)$ from the group without treatment (control).

B), while in the neo-regenerating myofibers, cell nuclei tend to move to the central area of the myofibers ${ }^{48}$ (Figure 7, D and E). Meanwhile, CD31 was immunostained to detect endothelial cell, and utrophin (dystrophin-related protein) was immunostained to localize myofibers and relatively mature blood vessels. ${ }^{61}$ Results showed that the relaxin-treated muscles contain a higher number of CD31-positive cells and faster formation of new blood vessels compared to the control muscles (Figure 7, G-I), indicating that angiogenesis and revascularization were also promoted with relaxin treatment.

Moreover, 10 days after muscle injury, the inflammatory reaction reflected by the number of inflammatory cells (CD8a and CD11b) was still found in the control muscles without relaxin administration (Figure 8, A, C, D, and $F$ ). This extended inflammation may partially explain the chronic wound and delayed healing that are often associated with aged muscle after injury. However, repression of the inflammatory reaction was observed in the injured muscles with relaxin treatment, with the number of CD8a- or CD11b-positive cells were both significantly decreased (Figure 8, B, C, E, and F). Our results indicate 

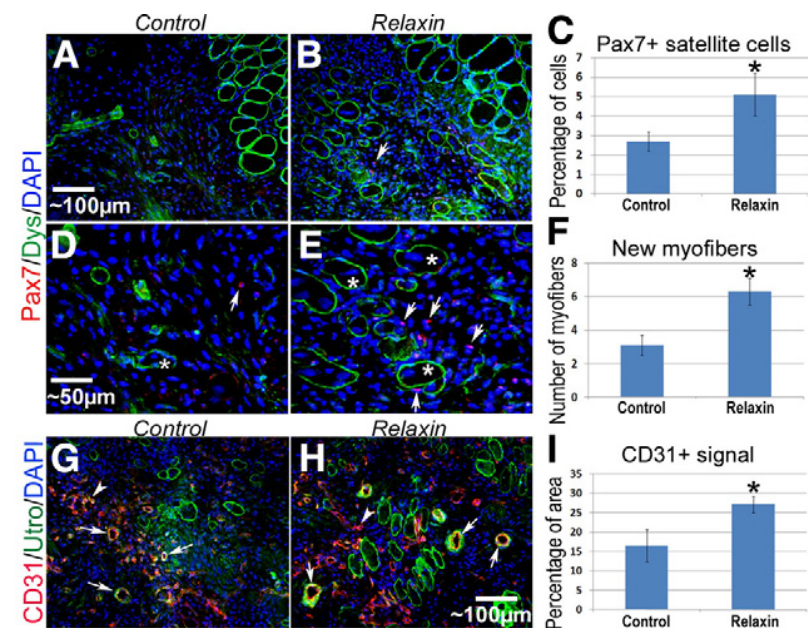

Figure 7. Relaxin administration improved satellite cell population and angiogenesis in injured muscle of 18 -month-old mice 10 days after injury. A-F: Ten days after muscle injury and 9 days after relaxin injection, there were more Pax7+ cells (red, arrows) present in the relaxin-treated muscles (B and E) compared to the control muscles (A and $\mathbf{D}$ ); also, the formation of new dystrophin + /centrally nucleated myofibers (green, asterisks) at the injured area was accelerated with relaxin treatment $(\mathbf{F})$. Image $\mathbf{D}$ or $\mathbf{E}$ is $\times 2$ magnification of image $\mathbf{A}$ or $\mathbf{B}$. Statistical analysis of the percentage of Pax7+ cells among all of the mononuclear cells at the area of muscle injury $(\mathbf{C})$, and the number of newly-formed myofibers in every $300 \times 300 \mu \mathrm{m}^{2}$ of area $(\mathbf{F})$ are shown. $\mathbf{G}$ and $\mathbf{H}$ : There was more CD31 signal (red) in single endothelial cells (arrowheads) or blood vessels (arrows) in the relaxin-treated muscles (H) compared to the control muscles (G). Utrophin (Utro, green) was immunostained to localize myofibers and relatively mature blood vessels, which were more obvious with relaxin administration at the time (10 days after injury). I: Statistical analysis of the percentage of CD31+ signal at the area of muscle injury. There is a significant difference $\left({ }^{*} P\right.$ value $\left.<0.05\right)$ from the group of young muscle $(\mathbf{C})$ or without treatment (control; $\mathbf{C}, \mathbf{F}$, and $\mathbf{I}$ ).

that, 10 days after muscle injury in the aged muscle, relaxin treatment may have reduced possible damages that could be caused by chronic inflammation. In addition, hematoxylin and eosin (H\&E) staining of the muscle sections further demonstrated that more new myofibers were generated with relaxin treatment in the aged muscle (Figure 8, G-I).

To investigate whether the level of TGF- $\beta 1$ within the injured skeletal muscle, which is critical in regulating muscle healing and fibrosis formation, ${ }^{12,63}$ may be influenced by relaxin administration, immunohistochemistry study for TGF- $\beta 1$ was conducted with sectioned skeletal muscles with or without relaxin administration. Results showed that TGF- $\beta 1$-positive signal was decreased within the relaxin-treated muscles, compared to the control muscles (Figure 8, J-L). Also, to further investigate whether the MMP activities within the injured skeletal muscle may be influenced by relaxin administration, a zymography study was conducted with skeletal muscle tissues. Results showed that the level of active MMP9, pro-MMP2, and active MMP2 had been increased within the relaxin-treated injured muscles, compared to the control muscles (Figure 8, M and $\mathrm{N}$ ).

\section{Discussion}

There is a complex cascade of events in muscle injury and repair, but regeneration and fibrosis are considered to be two competing processes during healing. ${ }^{3-4,62}$
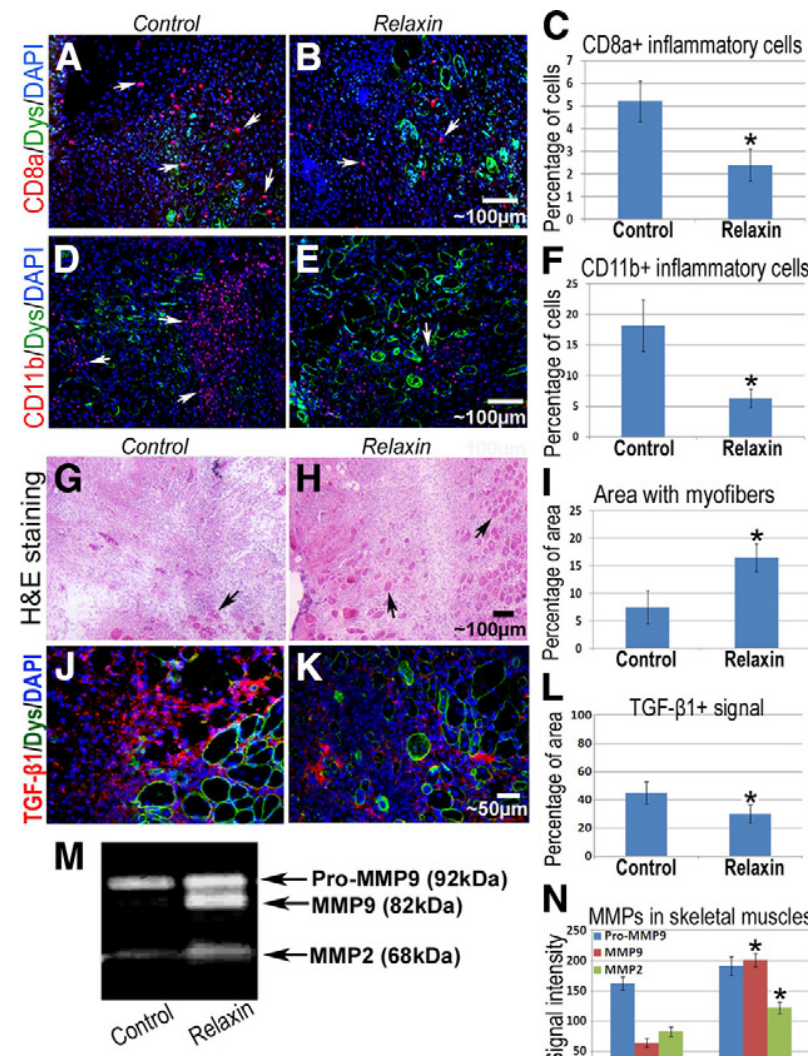

$\mathbf{N}$

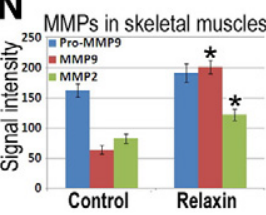

Figure 8. Relaxin administration affected inflammatory reaction, myofiber regeneration, TGF- $\beta 1$ depostion, and MMP activities in injured muscle of 18-month-old mice 10 days after injury. $\mathbf{A}$ and $\mathbf{B}$ : Ten days after muscle injury and 9 days after relaxin injection, the number of CD8a+ inflammatory cells (red) was reduced in the relaxin-treated muscles (B) compared to the control muscles (A). Myofibers were visualized with dystrophin (Dys, green). C: Statistical analysis of the percentage of CD8a + cells among all of the mononuclear cells at the area of muscle injury. $\mathbf{D}$ and $\mathbf{E}$ : The number of CD11b+ inflammatory cells (red) was significantly reduced in the relaxin treated muscles (E) compared to the control muscles (D). F: Statistical analysis of the percentage of CD11b+ cells among all mononuclear cells at the area of muscle injury. $\mathbf{G}$ and $\mathbf{H}$ : Result of H\&E staining showing myofibers (red, arrows) and cell nuclei (blue) in the injured area. I: Statistical analysis of the percentage area with myofibers. $\mathbf{J}$ and $\mathbf{K}$ : The level of TGF- $\beta 1$ (red) in the injured skeletal muscles is shown with immunohistochemistry, and dystrophin (Dys, green) was costained. L: Statistical analysis of the percentage of TGF- $\beta 1+$ area in the injured area of muscle. M: The level of active or proactive types of MMP2 and MMP9 within the injured muscle was analyzed with zymographic assay (gelatinase gel). N: The readout of the signal intensities in the gel, which is in correspondence with MMP activities. There is a significant difference $\left({ }^{*} P<0.05\right)$ from the group without treatment (control).

Fibrotic scar tissue formation in the injured muscle is characterized by an excessive accumulation of connective tissue and results in an irreversible loss of normal muscle function because the myofibers are replaced by non-functional scar tissue. ${ }^{62}$ The imbalance between regeneration and fibrosis in the healing process may be due to a limited number of activated satellite cells which is often associated with diseased or aged muscle, extended inflammation in chronic wound, and excessive profibrotic factors such as TGF- $\beta 1 .{ }^{3-4,6,63-64}$ Our previous study indicated that relaxin treatment improved muscle healing by promoting muscle regeneration and reducing fibrosis. ${ }^{33}$ The current experiment added more information about various direct or indirect effects of relaxin in the muscle healing process, which 
may include activation of MMPs, mobilization of satellite cells, activation of angiogenesis and revascularization, and repression of extended inflammatory reaction (chronic inflammation).

It has been considered that the regulation of MMPs activation is a critical step in promoting muscle healing. ${ }^{17-18,21,65-66}$ Myoblasts in the injured muscle originate from the activation, proliferation, and differentiation of satellite cells and are a main source for muscle regeneration. In this study, the increased activities of MMP2 and MMP9 in both $\mathrm{C} 2 \mathrm{C} 12$ myoblasts in vitro and injured skeletal muscle in vivo were observed with relaxin treatment. Additionally, MMP blocker GM6001 inhibited relaxin-promoted muscle cell differentiation and migration. These results suggest that MMP activation is possibly responsible for relaxin-promoted muscle regeneration during muscle healing. MMP1 can resolve fibrotic tissue by hydrolyzing type-I and III collagens in injured mus$\mathrm{cle}^{21}$; our previous study showed that MMP1 promotes muscle cell migration and differentiation both in vitro and in vivo. ${ }^{15}$ MMP2 and MMP9 can both be secreted by satellite cells. ${ }^{67,68}$ MMP2 was shown to be crucial in regulating myogenic cell fusion/elongation in coordination with TIMP2 and MT1-MMP. ${ }^{17,65}$ MMP9 functions in all stages of myogenic differentiation, ${ }^{17}$ and its activation increases the population of Sca-1-positive stem cells in the skeletal muscle. ${ }^{69}$ Therefore, based on our results, the up-regulated expression of MMPs with relaxin treatment may be a major contributor of the promoted cell migration and myogenic differentiation.

The hostile local microenvironment in aged muscle has been found to prevent the activation, recruitment, and differentiation of resident stem cells. The final outcome of muscle healing was suggested to be improved only when the microenvironment is modified to be favorable for stem cell functions. ${ }^{11-12}$ In the current study, we discovered that muscle healing in the aged muscle was improved by relaxin. The observation of an increased number of stem cells and accelerated muscle regeneration indicates that relaxin administration might have resulted in both stem cell activation and improvement of the local microenvironment in the aged muscle. The accelerated angiogenesis and controlled inflammation observed in our relaxintreated samples should have contributed to this modified microenvironment; a similar mechanism may also exist in the younger muscle. We suggest that this relaxin-modified microenvironment in the skeletal muscle can be related with the neutralizing effect of relaxin to TGF- $\beta 1$ activity and production, ${ }^{38,70}$ because TGF- $\beta 1$ has been identified as a determining factor in creating the hostile microenvironment in the aged muscle. ${ }^{12}$ Also, we suggest that the relaxin-regulated MMPs activity is involved because MMPs can act not only directly on myogenic cells ${ }^{15,19}$ but also on local microenvironment which includes ECM reconstruction and various profibrotic factors (ie, TGF- $\beta 1$ ). ${ }^{22,71-73}$ Moreover, it was found that MMP9 activation is helpful to restore the microcirculation and efficacy of cell therapy in aged dystrophic muscle, ${ }^{13}$ and MMPs/TIMPs ratio is in fact a crucial determinant for the scarless healing of early fetal wounds. ${ }^{74}$
Our results also indicated that relaxin treatment increased angiogenesis/revascularization in the injured muscle, which may be related with the activation of muscle progenitor cells including muscle stem cells. Muscle stem cells have multiple differentiation capacities including differentiation into angiogenic cells or blood vessel cells for angiogenesis/revascularization during muscle healing. ${ }^{75-76}$ Both the promoted activation of muscle progenitor cells and angiogenesis/revascularization with relaxin treatment may also be related with activated MMPs. MMP2 was found to mediate stretch-induced activation of satellite cells in a nitric oxide-dependent manner. ${ }^{77}$ MMP9 activation increased the population of Sca-1-positive stem cells which is not linage-determined, ${ }^{69}$ and can eventually differentiate into Pax7-positive myogenic cells or angiogenic cells in the regenerating skeletal muscle. ${ }^{53,78}$ Both MMP2 and MMP9 have also been found to play positive roles in mediating angiogenesis in regenerating skeletal muscle, ${ }^{79-80}$ including aged dystrophic muscle. ${ }^{13}$ Similarly, our unpublished data showed that blocking MMPs with GM6001 resulted in a decreased number of Pax7-positive satellite cells and delayed muscle healing. Based on these results, MMPs can be suggested to function as an important downstream mediator of the positive effects of relaxin in promoting muscle progenitor cells and angiogenesis. Also, the activated MMPs with relaxin treatment may contribute to the repressed fibrosis which was observed in later phases of muscle healing. ${ }^{33}$

It should be noted that the final quality of muscle healing was shown to be closely related with the initial time point of relaxin administration. Results in this study and our previous study demonstrate that an early administration of relaxin from the second or third day after muscle injury had generated an obviously improved muscle healing than late administration from 1 week to 2 weeks after injury. ${ }^{33}$ Based on the results of the current study, this time-dependent difference can be due to the effect of relaxin in activating satellite cells, controlling excessive inflammatory reaction, and promoting angiogenesis, which are all crucial events of muscle healing within the first few days after muscle injury. Our results strongly suggest that a minimal variation in the beginning phase of muscle healing could greatly alter the process and determine the final outcome.

Previous studies have discovered that relaxin reduces the recruitment of inflammatory leukocytes within the reperfused myocardium and other cardiovascular diseases (CVD). ${ }^{28,81}$ Relaxin represses inflammation during pregnancy, resulting in reduced incidence and severity of rheumatoid arthritis. ${ }^{82}$ Relaxin can also inhibit the activation of human neutrophils via the nitric oxide pathway. ${ }^{32}$ In fact, inflammatory reaction has been shown to play a complex and controversial role in the muscle healing process by promoting both muscle repair and injury. ${ }^{6}$ Macrophages remove the damaged cell debris that could impede muscle regeneration and stimulate the proliferation of satellite cells by releasing growth factors and cytokines; meanwhile, macrophages are able to promote muscle damage through the release of free radicals. ${ }^{24,83-84}$ Both the processes of debris removal and 
satellite cell proliferation occur within the first few days after muscle injury, while an extended inflammation can be related with fibrosis. In our results, the extended inflammation (Figure 8) rather than the acute inflammation (Figure 6) seemed to be more repressed with relaxin administration, which may indicate a controlled inflammatory reaction in favor of muscle healing.

Generally, results from this study demonstrate that relaxin administration can improve muscle healing not only by accelerating muscle regeneration and preventing fibrotic scar tissue formation but also by regulating MMP expression, activation of muscle precursors, angiogenesis/revascularization, and inflammatory reaction. Moreover, these functions of relaxin are effective in both young and aged skeletal muscle. Because the Phase II/III clinical trials of relaxin are moving forward, understanding the mechanisms behind relaxin in muscle healing could be necessary to guide the clinical application. Results from our studies will further benefit the application of relaxin to patients with skeletal muscle injuries and diseases.

\section{Acknowledgments}

We thank James Cummins for efforts in editing, and Haiying Pan, lan Bellayr, and Kyle Holden for technical assistance.

\section{References}

1. Li Y, Cummins J, Huard J: Muscle injury and repair. Curr Opin Orthopaed 2001, 12:409-415

2. Prisk V, Huard J: Muscle injuries and repair: the role of prostaglandins and inflammation. Histol Histopathol 2003, 18:1243-1256

3. Huard J, Li Y, Fu FH: Muscle injuries and repair: current trends in research. J Bone Joint Surg Am 2002, 84-A:822-832

4. Hurme $\mathrm{T}$, Kalimo H, Lehto M, Jarvinen M: Healing of skeletal muscle injury: an ultrastructural and immunohistochemical study. Med Sci Sports Exerc 1991, 23:801-810

5. Schultz E, McCormick KM: Skeletal muscle satellite cells. Rev Physiol Biochem Pharmacol 1994, 123:213-257

6. Tidball JG: Inflammatory processes in muscle injury and repair. Am J Physiol Regul Integr Comp Physiol 2005, 288:R345-R353

7. Sadeh M: Effects of aging on skeletal muscle regeneration. J Neurol Sci 1988, 87:67-74

8. Zacks SI, Sheff MF: Age-related impeded regeneration of mouse minced anterior tibial muscle. Muscle Nerve 1982, 5:152-161

9. Carlson BM: Factors influencing the repair and adaptation of muscles in aged individuals: satellite cells and innervation. J Gerontol A Biol Sci Med Sci 1995, 50:96-100

10. Bornemann A, Maier F, Kuschel R: Satellite cells as players and targets in normal and diseased muscle. Neuropediatrics 1999, 30:167-175

11. Carosio S, Berardinelli MG, Aucello M, Musaro A: Impact of ageing on muscle cell regeneration. Ageing Res Rev 2009, doi: 10.1016/ j.arr.2009.08.001

12. Carlson ME, Conboy MJ, Hsu M, Barchas L, Jeong J, Agrawal A, Mikels AJ, Agrawal S, Schaffer DV, Conboy IM: Relative roles of TGF-beta1 and Wnt in the systemic regulation and aging of satellite cell responses. Aging Cell 2009, 8:676-689

13. Gargioli C, Coletta M, De Grandis F, Cannata SM, Cossu G: PIGFMMP-9-expressing cells restore microcirculation and efficacy of cell therapy in aged dystrophic muscle. Nat Med 2008, 14:973-978

14. Bedair HS, Karthikeyan T, Quintero A, Li Y, Huard J: Angiotensin II receptor blockade administered after injury improves muscle regen- eration and decreases fibrosis in normal skeletal muscle. Am J Sports Med 2008, 36:1548-1554

15. Wang W, Pan H, Murray K, Jefferson BS, Li Y: Matrix metalloproteinase-1 promotes muscle cell migration and differentiation. Am J Pathol 2009, 174:541-549

16. Lluri G, Langlois GD, Soloway PD, Jaworski DM: Tissue inhibitor of metalloproteinase-2 (TIMP-2) regulates myogenesis and beta1 integrin expression in vitro. Exp Cell Res 2008, 314:11-24

17. Zimowska M, Brzoska E, Swierczynska M, Streminska W, Moraczewski J: Distinct patterns of MMP-9 and MMP-2 activity in slow and fast twitch skeletal muscle regeneration in vivo. Int J Dev Biol 2008, 52:307-314

18. Nishimura T, Nakamura $\mathrm{K}$, Kishioka $Y$, Kato-Mori $Y$, Wakamatsu J, Hattori A: Inhibition of matrix metalloproteinases suppresses the migration of skeletal muscle cells. J Muscle Res Cell Motil 2008, 29:37-44

19. Torrente Y, El Fahime E, Caron NJ, Bresolin N, Tremblay JP: Intramuscular migration of myoblasts transplanted after muscle pretreatment with metalloproteinases. Cell Transplant 2000, 9:539-549

20. El Fahime E, Torrente Y, Caron NJ, Bresolin MD, Tremblay JP: In vivo migration of transplanted myoblasts requires matrix metalloproteinase activity. Exp Cell Res 2000, 258:279-287

21. Bedair H, Liu TT, Kaar JL, Badlani S, Russell AJ, Li Y, Huard J: Matrix metalloproteinase- 1 therapy improves muscle healing. J Appl Physiol 2007, 102:2338-2345

22. Kaar JL, Li Y, Blair HC, Asche G, Koepsel RR, Huard J, Russell AJ Matrix metalloproteinase-1 treatment of muscle fibrosis. Acta Biomater 2008, 4:1411-1420

23. Irving-Rodgers HF, Rodgers RJ: Extracellular matrix in ovarian follicular development and disease. Cell Tissue Res 2005, 322:89-98

24. Merly F, Lescaudron L, Rouaud T, Crossin F, Gardahaut MF: Macrophages enhance muscle satellite cell proliferation and delay their differentiation. Muscle Nerve 1999, 22:724-732

25. Dina OA, Levine JD, Green PG: Muscle inflammation induces a protein kinase Cepsilon-dependent chronic-latent muscle pain. $J$ Pain 2008, 9:457-462

26. Stauber WT: Factors involved in strain-induced injury in skeletal muscles and outcomes of prolonged exposures. J Electromyogr Kinesiol 2004, 14:61-70

27. Bani D: Relaxin: a pleiotropic hormone. Gen Pharmacol 1997, 28:13-22

28. Bani D: Relaxin as a natural agent for vascular health. Vasc Health Risk Manag 2008, 4:515-524

29. Unemori EN, Erikson ME, Rocco SE, Sutherland KM, Parsell DA, Mak J, Grove BH: Relaxin stimulates expression of vascular endothelial growth factor in normal human endometrial cells in vitro and is associated with menometrorrhagia in women. Hum Reprod 1999, 14:800-806

30. Unemori EN, Lewis M, Constant J, Arnold G, Grove BH, Normand J Deshpande U, Salles A, Pickford LB, Erikson ME, Hunt TK, Huang X: Relaxin induces vascular endothelial growth factor expression and angiogenesis selectively at wound sites. Wound Repair Regen 2000, 8:361-370

31. Piccinni MP, Bani D, Beloni L, Manuelli C, Mavilia C, Vocioni F, Bigazzi M, Sacchi TB, Romagnani S, Maggi E: Relaxin favors the development of activated human T cells into Th1-like effectors. Eur J Immunol 1999, 29:2241-2247

32. Masini E, Nistri S, Vannacci A, Bani Sacchi T, Novelli A, Bani D: Relaxin inhibits the activation of human neutrophils: involvement of the nitric oxide pathway. Endocrinology 2004, 145:1106-1112

33. Negishi S, Li Y, Usas A, Fu FH, Huard J: The effect of relaxin treatment on skeletal muscle injuries. Am J Sports Med 2005, 33:1816-1824

34. Tang ML, Samuel CS, Royce SG: Role of relaxin in regulation of fibrosis in the lung. Ann NY Acad Sci 2009, 1160:342-347

35. Garber SL, Mirochnik Y, Brecklin CS, Unemori EN, Singh AK, Slobodskoy L, Grove BH, Arruda JA, Dunea G: Relaxin decreases renal interstitial fibrosis and slows progression of renal disease. Kidney Int 2001, 59:876-882

36. Bathgate RA, Lekgabe ED, McGuane JT, Su Y, Pham T, Ferraro T, Layfield S, Hannan RD, Thomas WG, Samuel CS, Du XJ: Adenovirusmediated delivery of relaxin reverses cardiac fibrosis. Mol Cell Endocrinol 2008, 280:30-38

37. Williams EJ, Benyon RC, Trim N, Hadwin R, Grove BH, Arthur MJ, Unemori EN, Iredale JP: Relaxin inhibits effective collagen deposition 
by cultured hepatic stellate cells and decreases rat liver fibrosis in vivo. Gut 2001, 49:577-583

38. Samuel CS: Relaxin: antifibrotic properties and effects in models of disease. Clin Med Res 2005, 3:241-249

39. Samuel CS, Unemori EN, Mookerjee I, Bathgate RA, Layfield SL, Mak J, Tregear GW, Du XJ: Relaxin modulates cardiac fibroblast proliferation, differentiation, and collagen production and reverses cardiac fibrosis in vivo. Endocrinology 2004, 145:4125-4133

40. Unemori EN, Amento EP: Relaxin modulates synthesis and secretion of procollagenase and collagen by human dermal fibroblasts. J Biol Chem 1990, 265:10681-10685

41. Formigli L, Francini F, Nistri S, Margheri M, Luciani G, Naro F, Silvertown JD, Orlandini SZ, Meacci E, Bani D: Skeletal myoblasts overexpressing relaxin improve differentiation and communication of primary murine cardiomyocyte cell cultures. J Mol Cell Cardiol 2009, 47:335-345

42. Formigli L, Perna AM, Meacci E, Cinci L, Margheri M, Nistri S, Tani A, Silvertown J, Orlandini G, Porciani C, Zecchi-Orlandini S, Medin J, Bani D: Paracrine effects of transplanted myoblasts and relaxin on post-infarction heart remodelling. J Cell Mol Med 2007, 11:1087-1100

43. Bonacchi M, Nistri S, Nanni C, Gelsomino S, Pini A, Cinci L, Maiani M, Zecchi-Orlandini S, Lorusso R, Fanti S, Silvertown J, Bani D: Functional and histopathological improvement of the post-infarcted rat heart upon myoblast cell grafting and relaxin therapy. J Cell Mol Med 2009, 13:3437-3448

44. Li Y, Negishi S, Sakamoto M, Usas A, Huard J: The use of relaxin improves healing in injured muscle. Ann NY Acad Sci 2005, 1041:395-397

45. Musaro A, McCullagh K, Paul A, Houghton L, Dobrowolny G, Molinaro $\mathrm{M}$, Barton ER, Sweeney HL, Rosenthal N: Localized Igf-1 transgene expression sustains hypertrophy and regeneration in senescent skeletal muscle. Nat Genet 2001, 27:195-200

46. Teerlink JR, Metra M, Felker GM, Ponikowski P, Voors AA, Weatherley BD, Marmor A, Katz A, Grzybowski J, Unemori E, Teichman SL, Cotter G: Relaxin for the treatment of patients with acute heart failure (PreRELAX-AHF): a multicentre, randomised, placebo-controlled, parallel-group, dose-finding phase llb study. Lancet 2009, 373:1429-1439

47. Kizawa H, Nishi K, Ishibashi $Y$, Harada M, Asano T, Ito $Y$, Suzuki N, Hinuma S, Fujisawa Y, Onda H, Nishimura O, Fujino M: Production of recombinant human relaxin 3 in AtT20 cells. Regul Pept 2003, 113:79-84

48. Nozaki M, Li Y, Zhu J, Ambrosio F, Uehara K, Fu FH, Huard J: Improved muscle healing after contusion injury by the inhibitory effect of suramin on myostatin, a negative regulator of muscle growth. Am J Sports Med 2008, 36:2354-2362

49. Lluri G, Jaworski DM: Regulation of TIMP-2. MT1-MMP, and MMP-2 expression during $\mathrm{C} 2 \mathrm{C} 12$ differentiation, Muscle Nerve 2005, 32:492-499

50. Das S, Mandal M, Mandal A, Chakraborti T, Chakraborti S: Identification, purification and characterization of matrix metalloproteinase-2 in bovine pulmonary artery smooth muscle plasma membrane. Mol Cell Biochem 2004, 258:73-89

51. Levy DE, Lapierre F, Liang W, Ye W, Lange CW, Li X, Grobelny D, Casabonne M, Tyrrell D, Holme K, Nadzan A, Galardy RE: Matrix metalloproteinase inhibitors: a structure-activity study. J Med Chem 1998, 41:199-223

52. Butler GS, Butler MJ, Atkinson SJ, Will H, Tamura T, Schade van Westrum S, Crabbe T, Clements J, d'Ortho MP, Murphy G: The TIMP2 membrane type 1 metalloproteinase "receptor" regulates the concentration and efficient activation of progelatinase A: a kinetic study. J Biol Chem 1998, 273:871-880

53. Seale $P$, Ishibashi J, Scime A, Rudnicki MA: Pax7 is necessary and sufficient for the myogenic specification of $\mathrm{CD} 45+: \mathrm{Sca} 1+$ stem cells from injured muscle. PLoS Biol 2004, 2:E130

54. Oustanina S, Hause G, Braun T: Pax7 directs postnatal renewal and propagation of myogenic satellite cells but not their specification. EMBO J 2004, 23:3430-3439

55. Sudo S, Kumagai J, Nishi S, Layfield S, Ferraro T, Bathgate RA, Hsueh AJ: H3 relaxin is a specific ligand for LGR7 and activates the receptor by interacting with both the ectodomain and the exoloop 2 . J Biol Chem 2003, 278:7855-7862

56. Halevy O, Novitch BG, Spicer DB, Skapek SX, Rhee J, Hannon GJ, Beach D, Lassar AB: Correlation of terminal cell cycle arrest of skeletal muscle with induction of p21 by MyoD. Science 1995, 267:1018-1021

57. Ishido M, Kami K, Masuhara M: In vivo expression patterns of MyoD, $\mathrm{p} 21$, and $\mathrm{Rb}$ proteins in myonuclei and satellite cells of denervated rat skeletal muscle. Am J Physiol Cell Physiol 2004, 287:C484-C493

58. Hirji N, Lin TJ, Bissonnette E, Belosevic M, Befus AD: Mechanisms of macrophage stimulation through CD8: macrophage CD8alpha and CD8beta induce nitric oxide production and associated killing of the parasite Leishmania major. J Immunol 1998, 160:6004-6011

59. Christensen JE, Andreasen SO, Christensen JP, Thomsen AR: CD11b expression as a marker to distinguish between recently activated effector CD8(+) T cells and memory cells. Int Immunol 2001, 13:593-600

60. Glynn P, Coakley R, Kilgallen I, O'Neill S: Neutrophil CD11b and soluble ICAM-1 and E-selectin in community acquired pneumonia, Eur Respir J 1999, 13:1380-1385

61. Wilson LA, Cooper BJ, Dux L, Dubowitz V, Sewry CA: Expression of utrophin (dystrophin-related protein) during regeneration and maturation of skeletal muscle in canine X-linked muscular dystrophy. Neuropathol Appl Neurobiol 1994, 20:359-367

62. Sato K, Li Y, Foster W, Fukushima K, Badlani N, Adachi N, Usas A, Fu $\mathrm{FH}$, Huard J: Improvement of muscle healing through enhancement of muscle regeneration and prevention of fibrosis. Muscle Nerve 2003, 28:365-372

63. Li Y, Foster W, Deasy BM, Chan Y, Prisk V, Tang Y, Cummins J, Huard $\mathrm{J}$ : Transforming growth factor-beta1 induces the differentiation of myogenic cells into fibrotic cells in injured skeletal muscle: a key event in muscle fibrogenesis. Am J Pathol 2004, 164:1007-1019

64. Mu X, Li Y: Conditional TGF-beta1 treatment increases stem cell-like cell population in myoblasts. J Cell Mol Med, 2010, doi: 10.1111/ j.1582-4934.2010.01042.x

65. Ohtake Y, Tojo H, Seiki M: Multifunctional roles of MT1-MMP in myofiber formation and morphostatic maintenance of skeletal muscle. J Cell Sci 2006, 119:3822-3832

66. Carmeli E, Moas M, Reznick AZ, Coleman R: Matrix metalloproteinases and skeletal muscle: a brief review. Muscle Nerve 2004 29:191-197

67. Guerin CW, Holland PC: Synthesis and secretion of matrix-degrading metalloproteases by human skeletal muscle satellite cells. Dev Dyn 1995, 202:91-99

68. Kherif S, Lafuma C, Dehaupas M, Lachkar S, Fournier JG, VerdiereSahuque M, Fardeau M, Alameddine HS: Expression of matrix metalloproteinases 2 and 9 in regenerating skeletal muscle: a study in experimentally injured and mdx muscles. Dev Biol 1999, 205:158-170

69. Bani C, Lagrota-Candido J, Pinheiro DF, Leite PE, Salimena MC, Henriques-Pons A, Quirico-Santos T: Pattern of metalloprotease activity and myofiber regeneration in skeletal muscles of $\mathrm{mdx}$ mice. Muscle Nerve 2008, 37:583-592

70. Wen Y, Zhao YY, Polan ML, Chen B: Effect of relaxin on TGF-beta1 expression in cultured vaginal fibroblasts from women with stress urinary incontinence. Reprod Sci 2008, 15:312-320

71. Zhang X, Chen X, Hong Q, Lin H, Zhu H, Liu Q, Wang J, Xie Y, Shang $X$. Shi S, Lu Y, Yin Z: TIMP-1 promotes age-related renal fibrosis through upregulating ICAM-1 in human TIMP-1 transgenic mice. J Gerontol A Biol Sci Med Sci 2006, 61:1130-1143

72. Hemmann S, Graf J, Roderfeld M, Roeb E: Expression of MMPs and TIMPs in liver fibrosis - a systematic review with special emphasis on anti-fibrotic strategies. J Hepatol 2007, 46:955-975

73. Selman M, Ruiz V, Cabrera S, Segura L, Ramirez R, Barrios R, Pardo A: TIMP-1, -2, -3 , and -4 in idiopathic pulmonary fibrosis. A prevailing nondegradative lung microenvironment? Am J Physiol Lung Cell Mol Physiol 2000, 279:L562-L574

74. Dang CM, Beanes SR, Lee H, Zhang X, Soo C, Ting K: Scarless fetal wounds are associated with an increased matrix metalloproteinaseto-tissue-derived inhibitor of metalloproteinase ratio. Plast Reconstr Surg 2003, 111:2273-2285

75. Deasy BM, Feduska JM, Payne TR, Li Y, Ambrosio F, Huard J: Effect of VEGF on the regenerative capacity of muscle stem cells in dystrophic skeletal muscle. Mol Ther 2009, 17:1788-1798

76. Cao B, Zheng B, Jankowski RJ, Kimura S, Ikezawa M, Deasy B Cummins J, Epperly M, Qu-Petersen Z, Huard J: Muscle stem cells differentiate into haematopoietic lineages but retain myogenic potential. Nat Cell Biol 2003, 5:640-646

77. Yamada M, Sankoda Y, Tatsumi R, Mizunoya W, Ikeuchi Y, Sunagawa $\mathrm{K}$, Allen RE: Matrix metalloproteinase-2 mediates stretch-induced 
activation of skeletal muscle satellite cells in a nitric oxide-dependent manner. Int J Biochem Cell Biol 2008, 40:2183-2191

78. Torrente Y, Tremblay JP, Pisati F, Belicchi M, Rossi B, Sironi M, Fortunato F, El Fahime M, D'Angelo MG, Caron NJ, Constantin G, Paulin D, Scarlato G, Bresolin N: Intraarterial injection of musclederived CD34(+)Sca-1(+) stem cells restores dystrophin in $\mathrm{mdx}$ mice. J Cell Biol 2001, 152:335-348

79. Rivilis I, Milkiewicz M, Boyd P, Goldstein J, Brown MD, Egginton S, Hansen FM, Hudlicka O, Haas TL: Differential involvement of MMP-2 and VEGF during muscle stretch- versus shear stress-induced angiogenesis. Am J Physiol Heart Circ Physiol 2002, 283:H1430-H1438

80. Johnson C, Sung HJ, Lessner SM, Fini ME, Galis ZS: Matrix metalloproteinase- 9 is required for adequate angiogenic revascularization of ischemic tissues: potential role in capillary branching. Circ Res 2004, 94:262-268
81. Perna AM, Masini E, Nistri S, Briganti V, Chiappini L, Stefano P, Bigazzi M, Pieroni C, Bani Sacchi T, Bani D: Novel drug development opportunity for relaxin in acute myocardial infarction: evidences from a swine model. FASEB J 2005, 19:1525-1527

82. Santora K, Rasa C, Visco D, Steinetz B, Bagnell C: Effects of relaxin in a model of rat adjuvant-induced arthritis. Ann N Y Acad Sci 2005, 1041:481-485

83. Chazaud B, Sonnet C, Lafuste P, Bassez G, Rimaniol AC, Poron F, Authier FJ, Dreyfus PA, Gherardi RK: Satellite cells attract monocytes and use macrophages as a support to escape apoptosis and enhance muscle growth. J Cell Biol 2003, 163:1133-1143

84. Lescaudron L, Peltekian E, Fontaine-Perus J, Paulin D, Zampieri M, Garcia L, Parrish E: Blood borne macrophages are essential for the triggering of muscle regeneration following muscle transplant. Neuromuscul Disord 1999, 9:72-80 